University of Pennsylvania Carey Law School

Penn Law: Legal Scholarship Repository

Faculty Scholarship at Penn Law

2016

\title{
A No-Tribunal SDRM and the Means of Binding Creditors to the Terms of a Restructuring Plan
}

Charles W. Mooney Jr.

University of Pennsylvania Carey Law School

Follow this and additional works at: https://scholarship.law.upenn.edu/faculty_scholarship

Part of the Banking and Finance Law Commons, Bankruptcy Law Commons, Conflict of Laws

Commons, Dispute Resolution and Arbitration Commons, International Economics Commons, International Law Commons, International Relations Commons, Law and Economics Commons, Legislation Commons, Public Administration Commons, and the Transnational Law Commons

\section{Repository Citation}

Mooney, Charles W. Jr., "A No-Tribunal SDRM and the Means of Binding Creditors to the Terms of a Restructuring Plan" (2016). Faculty Scholarship at Penn Law. 1607.

https://scholarship.law.upenn.edu/faculty_scholarship/1607

This Article is brought to you for free and open access by Penn Law: Legal Scholarship Repository. It has been accepted for inclusion in Faculty Scholarship at Penn Law by an authorized administrator of Penn Law: Legal Scholarship Repository. For more information, please contact PennlawIR@law.upenn.edu. 
Charles W. Mooney, Jr.*

\title{
A No-Tribunal SDRM and the Means of Binding Creditors to the Terms of a Restructuring Plan
}

DOI 10.1515/jgd-2015-0020

\begin{abstract}
This paper addresses two discrete but related and essential attributes of an SDRM. It first considers an SDRM that would provide a procedure for proposing and adopting a restructuring plan for a sovereign debtor's debt which would not involve any tribunal or administrator (a No-Tribunal SDRM). The paper examines the merits and feasibility of a No-Tribunal SDRM. In particular, the No-Tribunal SDRM proposed here would undertake the restructuring as if the sovereign debtor and its creditors were subject to the International Capital Markets Association Model Collective Action Clause regime. Second, this paper addresses the means by which a sovereign debt restructuring plan may become legally binding on a sovereign debtor's creditors. It focuses on the various legal structures that could be employed to cause a sovereign debtor's creditors to be legally bound by a restructuring plan - the implementation of a restructuring plan under an SDRM. This matter of binding creditors is an area of legal analysis that is somewhat underdeveloped and neglected in the literature. The paper addresses on implementation of a restructuring plan under a statutory approach - an SDRM imposed by rule of law. The manner of implementing an SDRM may be significant in several contexts, including the acceptability of the SDRM to political actors and market participants, the effectiveness of the operation of an SDRM, and the costs of devising and adopting an SDRM.
\end{abstract}

Keywords: default; enforcement; holdout; restructuring; sovereign debt.

\section{Introduction}

Based on developments in recent years and continuing proposals in the academic literature, it seems clear that available mechanisms for restructuring sovereign debt are inadequate and should be improved. For example, political economy constraints have provided powerful incentives for sovereign debtors to delay efforts to restruc-

*Corresponding author: Charles W. Mooney. Jr., University of Pennsylvania Law School, 3501 Sansom Street, Philadelphia, PA 19103, USA, e-mail: cmooney@law.upenn.edu 
ture unsustainable debt burdens and for creditors to resist write-offs ("too little, too late"), thus impairing the interests of debtor states and creditors alike (Guzman and Stiglitz [forthcoming]). In their recent survey of the prevailing problems and plausible options for improvements in sovereign debt restructuring processes, ${ }^{1}$ Guzman and Stiglitz conclude that the ultimate optimal approach would be the adoption of a formal multinational legal framework for sovereign debt restructurings (Ibid.). Proposals for such a formal restructuring framework are not new. Indeed, in 2002 senior officials of the International Monetary Fund (IMF) proposed a sovereign debt restructuring mechanism (SDRM) (Krueger 2002). The IMF's SDRM proposal ultimately was abandoned. Sean Hagan, the General Counsel of IMF, has provided a thoughtful analysis of the rejection of the SDRM proposal, including the strong opposition of the private sector (Hagan 2005). In the meantime, the sovereign debt securities market has embraced collective action clauses (CACs) as an important component of a strategy for facilitating the restructuring of sovereign debt (IMF 2013). A CAC permits a supermajority (e.g. 75\%) of debt security holders of an issuer of sovereign debt securities to amend payment terms (and other important terms) and to bind all security holders to the terms of the amendment (Ibid.).

CACs embody a voluntary, contractual, and market-based approach to sovereign debt restructuring. More recently, "aggregated" CACs, operable across various issues of debt securities, have been mandated for the Eurozone (EFC 2012a,b; EFC 2014). And in 2014 the International Capital Markets Association (ICMA) published forms of standard aggregated CACs (Model CACs) for incorporation into debt security documentation (ICMA 2014). In its simplest form, an aggregated "single limb" CAC under the Model CACs would provide that a supermajority vote of the holders of $75 \%$ of the outstanding principal amount of all outstanding issues of debt securities could modify the payment and other material terms of the securities. No supermajority (or even majority) vote of any particular issue of debt securities would be required. The Model CACs already have been incorporated in new debt security issues by several sovereign issuers. ${ }^{2}$

1 Guzman and Stiglitz explain that the lack of clarity resulting from the absence of an international bankruptcy procedure for sovereign debtors can lead to chaos (Guzman and Stiglitz [forthcoming]). They note that a good system would provide incentives for efficient behavior of lenders and debtors at the time credit is extended and at the time of resolving a debt crisis (Ibid.). They also point out that the current flawed system over-penalizes debtors and encourages bailouts instead of efficient mechanisms for restructuring (Ibid.). Moreover, the currently prevailing system, they observe, fails to take account of "informal creditors" such as pensioners and those relying on government benefits such as health benefits and education (Ibid.).

2 For example, in October 2014 Kazakhstan incorporated the Model CACs into a debt issue and Vietnam and Mexico followed suit in November 2014 (Lee 2014a,b; Thomas 2015). Guzman and Stiglitz conclude that the new Model CACs are improvements over earlier forms of CACs (Guzman 
Notwithstanding the rejection of the IMF's SDRM proposal and the widespread adoption of CACs, calls for more formal mechanisms for restructuring sovereign debt did not cease (see, e.g. Buckley 2009). More recent years have seen a resurgence of such proposals (see, e.g. Buchheit and Gulati 2010a,b; Paulus 2013; Gelpern 2013; Paulus and Tirado 2013; Schwarcz [forthcoming]). Some recent proposals have been prompted, at least in part, by the recent financial crises in the Eurozone (see, e.g. Gianviti et al. 2010; Paulus 2014), Moreover, resolutions passed by the United Nations General Assembly in 2014 called for international negotiations on "a multilateral framework for sovereign debt restructuring processes" and established an ad hoc committee (Ad Hoc Committee) for that purpose. ${ }^{3}$ The Ad Hoc Committee met three times in 2015 and in July 2015 issued a set of Principles on Sovereign Debt Restructuring Processes ${ }^{4}$ (Ad Hoc Committee 2015; UNCTAD 2015a,b; UN 2015).

Renewed discussion and commentary on the need for an $\mathrm{SDRM}^{5}$ and its appropriate content are timely. But it must be noted that the IMF, the US and the European Union (EU) oppose a binding multilateral restructuring framework. Indeed, both the US and the EU took the position that they would not even participate in any discussions of a formal framework ${ }^{6}$ (Muchhala 2014). None of the US, the EU, EU member states, Japan, or the IMF attended the meetings of the Ad Hoc Committee. ${ }^{7}$ Given this rather hostile environment for consideration of an

and Stiglitz [forthcoming]). However, they also detail the limitations of a contractual approach, including the many existing debt contracts that will mature more that 10 years from now, intercreditor fairness issues, and negative externalities imposed by governments that opt for shortrun benefits (Ibid.).

3 Towards the Establishment of a Multilateral Legal Framework for Sovereign Debt Restructuring Processes, G.A. Res. 304, U.N. GAOR, 68th Sess. (2014) at 4 (September 2014 UN Resolution); Modalities for the Implementation of Resolution 68/304, entitled "Towards the Establishment of a Multilateral Legal Framework for Sovereign Debt Restructuring Processes,” G.A. Res. 247, U.N. GAOR, 69th Sess. (2014).

4 At the second meeting UNCTAD made available the work product of its Working Group on a Debt Workout Mechanism, which it established in 2013. Sovereign Debt Workouts: Going Forward, Roadmap and Guide (UNCTAD 2015c).

5 Except for specific references to the earlier IMF SDRM proposal, I use the SDRM acronym here to refer generically to any formal, legally binding sovereign debt restructuring mechanism.

6 "[T]he fact that only the US explicitly rejected an intergovernmental negotiation on the draft resolution bears repeating, as even the other 10 countries that voted against the [September 2014 UN Resolution] ... seem willing to engage in some type of intergovernmental process going forward.” (Muchhala 2014: p. 5); "Neither the EU nor Member States will participate in discussions aiming at the establishment of a binding multilateral legal framework for sovereign debt restructuring processes" (EU 2014).

7 Not only did the US, the EU, and EU member states fail to attend the meetings of the Ad Hoc Committee (see note 6), but also Japan and the IMF did not attend the meetings. E-mail from Hironori Matsuo, Attorney, Civil Affairs Bureau, Ministry of Justice, Japan, to author 
SDRM, the Centre for International Governance Innovation and Columbia University Initiative for Policy Dialogue deserve much gratitude for keeping the enormously important subject of sovereign debt restructuring on the front burner by their timely sponsorship of the September 2015 conference.

This paper accepts the proposition that an efficient SDRM would be an effective means of addressing the "too little, too late" problem. It addresses two discrete but related and essential attributes of an SDRM. It first considers an SDRM that would provide a procedure for proposing and adopting a restructuring plan for a sovereign debtor's debt which would not involve any tribunal or administrator (a No-Tribunal SDRM). ${ }^{8}$ In contrast, virtually all earlier proposals for an SDRM proceeded on the basis that some form of tribunal or administrator would be necessary for overseeing (in some fashion) a sovereign debt restructuring proceeding. The paper examines the merits and feasibility of a No-Tribunal SDRM. In particular, the No-Tribunal SDRM proposed here would undertake the restructuring as if the sovereign debtor and its creditors were subject to the Model CAC regime. In addition to embodying a novel and interesting structure for an SDRM and one that eliminates the difficult hurdle of identifying a satisfactory tribunal adoption of a No-Tribunal SDRM would accommodate flexibility in selecting the manner of implementing the SDRM, i.e. causing it to be binding on the sovereign debtor's creditors.

Second, this paper addresses the means by which a sovereign debt restructuring plan may become legally binding on a sovereign debtor's creditors. . In contrast, earlier SDRM proposals generally have described and assessed the details of the formulation and content of a sovereign debt restructuring plan and the procedural steps involved in a making a restructuring plan effective. ${ }^{10}$ This paper takes a very different approach. It generally leaves these details aside. Instead, it focuses primarily on the various legal structures that could be employed to cause a sovereign debtor's creditors to be legally bound by a restructuring plan. I refer to the adoption of such structures as the implementation of a restructuring plan. Aside from contractual approaches to restructuring, this matter of

(Oct. 30, 2015, 08: 05 EDT) (on file with author); E-mail from Sean Hagan, General Counsel, IMF, to author (October 18, 2015, 09:32 EDT) (on file with author). I attended the first 2 days of the first meeting and the second 2 days of the second meeting as a member of the NGO observer delegation of the International Insolvency Institute.

8 The No-Tribunal SDRM is considered in more detail in Part 4.

9 Guzman and Stiglitz identify the problems of "holdout" creditors in general and the "vulture funds" in particular as sources of inefficiency and even resulting in the impossibility of a sovereign debt restructuring (Guzman and Stiglitz [forthcoming]).

10 See the authorities relating to SDRM proposals cited in the Introduction. My recent paper, discussed in Part 2., also follows this pattern (Mooney 2015). 
binding creditors is an area of legal analysis that is somewhat underdeveloped and neglected in the literature. Of course, binding creditors that have agreed to be bound by a process (a contractual approach), as under the operation of a CAC, is relatively straightforward both operationally and normatively. ${ }^{11}$ Accordingly, the paper focuses on implementation of a restructuring plan under a statutory approach imposed by rule of law. While the various approaches implicate issues that are quite technical as a matter of legal analysis, the implementation scheme or schemes chosen for an SDRM are enormously important. The manner of implementing an SDRM may be significant in several contexts, including the acceptability of the SDRM to political actors and market participants, the effectiveness of the operation of an SDRM, and the costs of devising and adopting an SDRM.

Whether a completed restructuring plan under an SDRM would be binding on a sovereign debtor's creditors necessarily involves the application of the law of the state that has enacted the SDRM. But it also often might implicate the law of one or more other states where the binding nature of the plan might be judicially tested, such as in the context of a creditor's efforts to enforce pre-restructuring debt or in a creditor's legal challenges to a restructuring process or plan. While an analysis of the relevant issues under all of the various laws that might apply is beyond the scope of this paper, it offers a roadmap for future analysis and evaluation of the means of implementing an SDRM considered here. ${ }^{12}$

The remainder of this paper proceeds as follows. Part 2 provides background by way of a summary of the contents of another recent paper to which several references are made throughout this paper. Part 3 outlines the working hypotheses and assumptions that are necessary to situate the discussions of the No-Tribunal SDRM and the implementation of an SDRM. Part 4 then examines in detail the No-Tribunal SDRM. Next, Part 5 identifies and explains alternative and conjunctive approaches to the non-contractual implementation an SDRM - binding creditors under a sovereign debt restructuring plan. It introduces the subject by exploring relevant legal issues and impediments under the law of a state that has enacted an SDRM as well as the law of other states that may be implicated.

11 The contractual approach would include an SDRM provided for under the terms of a debt contract, as proposed by Christoph Paulus and Ignacio Tirado (see Paulus 2013; Paulus and Tirado 2013).

12 Steven Kargman and I have suggested to the leadership of the International Insolvency Institute (III) that it consider the possibility of undertaking a systematic and global study of the enforceability of a sovereign debt restructuring plan pursuant to a statutory framework, on a multi-jurisdictional basis, whether by domestic statute, convention or other treaty, or otherwise. If the III or another party should undertake such a project, perhaps the analysis of the means of implementing an SDRM presented here will be of some value. For background on the III, see its website at http://iiiglobal.org. 
Part 6 then considers the feasibility of the adoption of an SDRM by states. Part 7 concludes the paper.

\section{Background: An Appropriate Framework for an SDRM}

In another recent paper, A Framework for a Formal Sovereign Debt Restructuring Mechanism: The KISS (Keep it Simple, Stupid) Principle and Other Guiding Principles (Mooney 2015) (Framework), I outlined in detail my vision of an appropriate the framework and content of an SDRM. While Framework builds on earlier SDRM proposals, this paper, in turn, relies on and builds on Framework. For this reason it is necessary to summarize here the content of Framework and to provide an overview of the SDRM proposed there.

The approach that I proposed in Framework would have the SDRM mimic the structure and operation of the Model CACs, but in the context of supermajority voting of claims in the process of approving a restructuring plan. The proposed SDRM embraced four overarching principles: (i) observing the KISS (keep it simple, stupid) principle, (ii) following the Model CACs, (iii) limiting the discretion of any tribunal or administrator of a restructuring proceeding, and (iv) addressing only major current problems. The proposed approach sought to meet the concerns of stakeholders that currently oppose an SDRM as well as the concerns of those that support an SDRM approach.

The proposal in Framework called for an implementing international, multilateral convention (or reciprocal model law) that would obligate an adopting state to recognize a restructuring plan approved under the law of another adopting state..$^{13}$ However, this obligation to recognize another state's reorganization plan would apply only if the other state's restructuring law (SDRM) met certain qualifying criteria as specified in the convention or model law. Moreover, the recognition obligation would be subject to certain exceptions (along the lines of widely accepted exceptions to the recognition and enforcement of commercial arbitration awards). In addition, the proposed approach would have a longer reach than earlier proposals in its methods of binding a debtor state's creditors under an approved restructuring plan. For example, after approval of a debtor state's restructuring plan by a supermajority of all classes of creditors, nationals of all adopting states would be prohibited from enforcing their claims against the

13 The convention or model law generally would follow the structures described below in Part 5.3.1-5.3.3. 
debtor state (even through procedures in non-adopting states) or from transferring their pre-restructuring claims to nationals of non-adopting states (unless the transferees agreed to be bound by the same restrictions applicable to adopting state nationals). ${ }^{14}$

The proposal in Framework also details the requirements for a state's SDRM to qualify for recognition; the convention or model law would spell out these requirements (Mooney 2015, Part III). The requirements would include the following: (i) similar claims of creditors would be classified together, with voting structures following the Model CACs (ii) approval of a restructuring plan would require acceptance by a supermajority of each class of claims, (iii) only a debtor state could commence a proceeding, (iv) an administrator to oversee the process would have very little discretion, ${ }^{15}(\mathrm{v})$ all indebtedness of a state would be eligible for restructuring, but the indebtedness actually to be restructured would be specified by the debtor state in its proposed plan, (vi) disputed claims would be resolved by the administrator, by arbitration, or by a court whose law applies to the disputed debt, (vii) priorities among creditors would remain as under the applicable law outside the QSDRL, (viii) no provision would be made for priority interim financing (instead, an international framework would be developed outside of the sovereign debt restructuring law itself), (ix) no provision for cramdown of dissenting classes of creditors would be imposed, and (x) other requirements for approval of a plan, such as being proposed in good faith, not unfairly discriminating, being in the best interests of creditors, and being feasible would be determined by the requisite supermajority votes of creditors, not by the administrator or any other tribunal.

Finally, the SDRM proposed in Framework would address the objections raised by SDRM opponents that declined to participate in the work of the Ad Hoc Committee, such as the US, the EU, and the IMF (Ibid., Part IV). As explained in Framework, a properly structured SDRM could embrace the standards of being market-based, voluntary, and contractual - standards advocated by those who have opposed implementation of an SDRM. In a fashion similar to the structure provided to a securities market by a securities exchange, a properly constructed SDRM could provide a market structure under which creditors could vote according to their interests. The principal involuntary component would be the binding of minority dissenting creditors by the supermajority, but that is a result currently in place under CACs and embraced even by those who have in the past opposed the institution of an SDRM.

14 This feature generally would follow the structure described below in Part 5.3.4.

15 The possibility of dispensing entirely with any administrator or tribunal - a No-Tribunal SDRM - was briefly mentioned but not developed in Framework. 


\section{Working Hypotheses and Assumptions}

The paper proceeds on the assumption that an insolvency proceeding of a distressed debtor state is conducted pursuant to an SDRM under the law of a sovereign state (the "relevant insolvency state") ${ }^{16}$ and that a restructuring plan has become effective under that law (the "law governing the SDRM"). The relevant insolvency state may or may not be the sovereign debtor state. However, it is highly likely, and consequently plausible to assume, that a sovereign debtor would choose to restructure its debt under its own law, i.e. that the sovereign debtor state itself would be the relevant insolvency state and the law of that state would be the law governing the SDRM. The discussion of a No-Tribunal SDRM and the implementation of an SDRM in Parts 4 and 5, respectively, generally incorporates this assumption.

The reference to the conduct of an "insolvency proceeding" reflects the further assumption that the SDRM possesses the characteristics generally associated with an insolvency law, such as requiring approval of a restructuring plan by a supermajority of all classes of creditors, a rational basis for classification of creditors for purposes of voting, initiation of the proceeding and proposal of a restructuring plan by the sovereign debtor state, and other provisions that generally provide for fair and reasonable treatment of creditors. ${ }^{17}$ The "restructuring plan" contemplated here would provide for the modification of the terms of a state's sovereign debt. The modification could include the extension of maturities of restructured debt, reducing the principal amount of the debt, modifying the interest rates applicable to the debt, or otherwise modifying the terms of debt.

Finally, it is necessary to consider the circumstances that might follow the effectiveness of a restructuring plan under the law governing the SDRM under which the plan was adopted and made effective. The restructuring plan would be effective and recognized under the law governing the SDRM in the relevant insolvency state. Were a creditor to seek to enforce a preexisting, prerestructuring debt contract (such as by commencing a lawsuit or enforcing a judgment against the debtor state's assets), courts of the relevant insolvency state would be obliged to deny and prohibit such enforcement steps. But what if, for example, a creditor

16 This simplifying assumption is adopted for convenience. However, the restructuring plan also could become effective under international law, such as under the Articles of Agreement of the IMF or pursuant to another international agreement or treaty. Note that even if the relatively "clean" and pervasive approach of amending the IMF Articles were taken, it would be necessary nonetheless to consider the techniques for implementing an SDRM - binding creditors addressed here. A court outside the relevant insolvency state must take away from any SDRM and recognition convention or law clear directions on what it must do and on what basis.

17 See, e.g. Part 2, above (summarizing the content of the SDRM proposed in Framework). 
holding a judgment based on a prerestructuring debt contract sought to enforce that debt in courts of another state? Whether such enforcement would be permitted would depend on whether the restructuring plan had been successfully implemented to the end that the creditor, the courts of the other state, or either, were bound by the terms of the restructuring plan. This is the central subject addressed in more detail below in Part 5.

\section{A No-Tribunal SDRM}

One of the sticking points leading to the ultimate demise of the IMF's SDRM proposal was concern over the selection of a tribunal that would be satisfactory to all stakeholders. ${ }^{18}$ An SDRM structure could overcome that hurdle by eliminating altogether any role for a tribunal or administrator in the administration or oversight of a formal restructuring process. ${ }^{19}$ Imagine an insolvency law (an SDRM) of the debtor state (a law of the relevant insolvency state as the law governing the SDRM) providing for an SDRM that followed the structure and procedures of the Model CACs as closely as possible,${ }^{20}$ including the roles and services of a Calculation Agent (ICMA 2014: p. 9), ${ }^{21}$ Aggregation Agent (Ibid., 10-12), ${ }^{22}$ and Noteholders'

18 See Hoffman 2014: "[T]hese [SDRM] approaches seem to face insurmountable opposition from legislators and governments who fear the intrusive consequences on sovereign autonomy,” citing Orzan 2004.

19 Novel as the no-tribunal approach may seem by modern traditions, there is an historical antecedent. As Stefan Riesenfeld has explained: During a period lasting from the middle of the sixteenth century to the middle of the seventeenth century Chancery or Privy Council aided the debtor in achieving such settlements [with creditors] by compelling a dissenting minority of creditors to assent to compositions concluded with the majority. But subsequently a change occurred. The Chancery practice of "bills of conformity" was abolished in 1621 and the Privy Council lost jurisdiction over aid to debtors in 1649 (Riesenfeld 1987: p. 431). While Chancery and the Privy Council provided implementation or enforcement, it was the agreement of the majority of the creditors outside of any supervision by a tribunal that was the key to binding dissenting creditors (Ibid.).

20 Note that this is essentially what was achieved by Greece's "mopping up law," which effectively imposed CACs on bonds governed by the law of Greece (Boudreau 2012).

21 Paragraph (g), Claims Valuation (Meetings of Noteholders; Written Resolutions), of the Model CACs deals with the appointment, by the issuer of debt securities, of a Calculation Agent for calculation of par value of securities.

22 Paragraph (a), Appointment (Aggregation Agent; Aggregation Procedures), of the Model CACs deals with the appointment, by the Issuer of debt securities, of an Aggregation Agent for calculation of whether a proposed modification has approved by the requisite amount outstanding of debt securities. 
Committee (and other relevant creditors' committees) (Ibid., 13-15). ${ }^{23}$ The debtor state would propose the terms of the restructuring plan (i.e. proposed modifications of the terms of debt included in Reserved Matters (Ibid., 6-8) ${ }^{24}$ and other modifications) and creditors would be called upon to vote under one of the structures contemplated by the Model CACs (Ibid., 3-6).25

The absence of a tribunal to oversee and administer the insolvency proceeding under a NO-Tribunal SDRM would not mean that parties would not have access to courts or other relevant dispute resolution mechanisms ${ }^{26}$ for the resolution of disputes or challenges to the restructuring process or its results (i.e. putative acceptance or nonacceptance of a restructuring plan). ${ }^{27}$ For example, if the debtor state has submitted to the jurisdiction of the courts of a state the law of which governs certain debt of the debtor state, a creditor holding that debt could seek relief in those courts. In other situations aggrieved creditors might be permitted to seek

23 Paragraph (a)(i), Appointment (Supplementary Provisions; Noteholders' Committee), deals with the appointment, by the holders of 25 percent of the principal amount of outstanding debt securities, of a person or committee to represent holders of debt securities. To the extent that debt to be restructured included debt other than debt securities a committee or committees to represent the holders of such debt could be appointed in similar fashion. See the discussion below of debt that could be subject to restructuring under an SDRM. See also Mooney 2015, Part III.A.5.

24 Paragraph (e), Reserved Matters (Meetings of Noteholders; Written Resolutions), of the Model CACs lists the Reserved Matters as to which a modification is subject to supermajority approval under the Model CACs).

25 The Model CACs provide, in paragraphs (b), Modification of this Series Only, (c) Multiple Series Aggregation - Single limb voting, and (d), Multiple Series Aggregation - Two limb voting (Meetings of Noteholders; Written Resolutions), for a range of available alternative voting structures. A "single limb" structure would require approval of a modification by $75 \%$ of the aggregate outstanding principal amount of the debt securities of all issues as to which the modification would apply. A "two limb" structure would require approval of a modification by $66-2 / 3 \%$ of the aggregate outstanding principal amount of the debt securities of all issues as to which the modification would apply and approval by $50 \%$ of each issue of such debt securities. Also, a debtor state's proposal could mix and match voting structures. For example, one subset of debt securities could be subject to a single limb voting structure and another set could be subject to a two limb structure.

26 Even without a tribunal to administer or oversee the proceeding, the insolvency law creating the SDRM could provide for binding arbitration on discrete issues, such as the validity or amount of a creditor's claim.

27 Under the approach proposed in Framework, there would be a relatively narrow range of exceptions to an adopting states obligation to recognize an effective restructuring plan, along the lines of, but somewhat broader that the exceptions provided under the New York Convention for commercial arbitration awards. Mooney 2015, Part II.B.2.c., discussing exceptions to recognition obligation; United Nations Convention on the Recognition and Enforcement of Foreign Arbitral Awards, Article V (providing exceptions to duty to recognize and enforce arbitral awards). 
relief in the courts of the relevant insolvency state or, if different, the debtor state. Of course, nothing in the Model CACs eliminates the availability of appropriate courts in connection with disputes concerning the operation of a CAC. ${ }^{28}$

An insolvency law that established a No-Tribunal SDRM based on the Model CACs necessarily would contain provisions that supplement the terms of the Model CACs. Merely cloning the Model CAC structure would not be adequate. In particular, a scheme for the classification of claims would be necessary. ${ }^{29}$ The sovereign debt contemplated by the Model CACs - essentially long-term debt securities - is generally homogeneous. But an SDRM could accommodate restructuring not only of debt securities but other debt, such as bank loans (syndicated or single-bank) and trade debt. ${ }^{30}$ For present purposes, it is sufficient to take note of the need for a classification scheme to guide - and constrain - the debtor state in its proposal of a voting structure for creditor acceptance (or not) of a restructuring plan.

A functional insolvency law establishing a No-Tribunal SDRM no doubt would include other provisions and address other matters than those dealt with by the Model CACs. Not unlike other SDRM proposals, in addition to considering classification and voting of claims and the types of debt that might be restructured, the content of the SDRM proposed in Framework dealt with matters such as disputed claims, creditor priorities, and various possible additional conditions to the effectiveness of a restructuring plan. ${ }^{31}$ The additional complexity inherent in any insolvency law, such as a No-Tribunal SDRM, necessarily means the regime would harbor a greater potential for disputes when compared to CACs, even aggregated CACs as contemplated by the Model CACs.

Other differences between the operation of the Model CACs and any SDRM, including a No-Tribunal SDRM, also should be acknowledged. The issuance of the debt securities contemplated by the Model CACs normally would involve an official registry listing security holders of record. But that would not necessarily be the case for bank loans and certainly would not apply in the case of trade debt.

28 Note, however, that under the Model CACs an acceleration of principal under an issue of debt securities following an event of default requires notice by holders of at least $25 \%$ of the outstanding principal amount of the securities and, once accelerated, at least 50\% approval is required to give notice that an event of default has been cured and that an acceleration is withdrawn, under the Model CACs, Supplementary Provisions, Events of Default, paras. (a), (b) (ICMA 2014: p. 16).

29 See Mooney 2015, Part III.A.2., 3., discussing creditor approval, classification of claims, and voting. The Model CACs, however, provide a debtor state with considerable flexibility is proposing a voting structure for a modification of terms, as discussed above.

30 See Mooney 2015, Part III.A.7., discussing scope of debt eligible for restructuring, subject to debtor state's proposal.

31 See Part 2 above for a summary of the contents of the SDRM proposed in Framework. 
For this reason, the operation of any SDRM with a scope of coverage broader than debt securities would present a greater challenge than the Model CACs in terms of the identification of the debtor state's debt and the holders of that debt. In this connection, the operation of an SDRM would benefit from the institution of a global sovereign debt registry (see Mooney 2015, Part III.A.3.).

A fundamental difference between the Model CACs and the No-Tribunal SDRM envisioned here is the nature of the mechanism employed to bind creditors. The Model CACs would be contractually adopted as terms of debt securities. The debt security holders would be contractually bound to accept the results of a modification of terms through the operation of the Model CACs as incorporated into their securities. However, the No-Tribunal SDRM contemplated here would be the product of the enactment of an insolvency law and a restructuring plan would become binding on a debtor state's creditors through one or more of the approaches described below in Part 5. The extent to which this difference would be important to existing and prospective creditors and debtor states is discussed briefly below in Part 6.

As described above, the No-Tribunal SDRM would be a statutory mechanism adopted pursuant to the enactment of an "insolvency law." Given the absence of any tribunal to administer a restructuring proceeding, one might question whether such a statute would be an insolvency law, as that term (and concept) is generally understood. ${ }^{32}$ But because the No-Tribunal SDRM, coupled with effective methods of implementation for binding creditors, would contain many of the usual components of an insolvency law, I believe that the term is apt. But the question largely is a red herring. As explained below in Part 5.2, the presence or absence of a tribunal might determine whether a state will consider recognition of a restructuring plan adopted under the SDRM of another state a matter of recognition of an insolvency judgment or a question of the application of its choice-of-law rules. So long as the recognition is given, however, the characterization would appear to be of little moment beyond attention to doctrinal niceties. The important question is whether a state will recognize as valid and effective a restructuring plan adopted pursuant to the SDRM and which provides for the modification and discharge of debt.

Finally, I make no claim that a No-Tribunal SDRM (or the attributes of an SDRM proposed in Framework) would constitute an optimal regime. As explained in Framework:

32 In this context I use the term in a broad sense to include restructuring and rehabilitation regimes such as an SDRM. Obviously, the concept of "insolvency" in the balance-sheet, assets versus liabilities sense has no traction in the case of a state that cannot be liquidated in the manner of a private entity with a distribution of its net asset value to its creditors. 


\begin{abstract}
The goal of the proposal is not to offer an optimal SDRM. Instead, the goal is to explore a system that could be a substantial improvement over the status quo and that could, over time, actually gain widespread acceptance in the international community. The system should address the major deficiencies that currently exist. To be successful, a system must meet and respond to the normative and practical objections of important stakeholders who currently oppose the development of a formal restructuring mechanism. A strategy of proposing a potentially optimal and comprehensive regime - while hoping against hope that important stakeholders that oppose the formal mechanism approach will conclude that they have been misguided and admit their errors - is unlikely to be successful. So far, the facts on the ground bear this out.
\end{abstract}

(Mooney 2015)

\title{
5 Non-Contractual Implementation of an SDRM: “Binding” Creditors under a Sovereign Debt Restructuring Plan
}

This Part outlines various plausible methods by which a restructuring plan could be made binding on a debtor state's creditors. It also identifies several legal issues that bear on the effectiveness and feasibility of such methods.

\subsection{Operation of Law Governing SDRM: Constitutional Impediments, Pre-Existing Creditors (Retroactivity), and Extraterritorial Application}

The SDRM would, no doubt, provide that all creditors are legally bound by a restructuring plan that becomes effective pursuant to the SDRM. The result of creditors being legally bound by the plan would be that the plan's modification of the creditors' claims would be valid and effective. The creditors so bound would be specified to include any dissenting creditors that have not approved or consented to the plan, including creditors whose claims arose before the SDRM had be come effective under the law governing the SDRM. An obvious initial question would be whether the entity (such as a state's legislative body) or person (such as an executive officer of a state) that enacted or promulgated the SDRM had, under the law governing the SDRM, the constitutional and other authority and power to provide for such broad and retroactive effects. The effects would be retroactive in the sense that pre-existing creditors' rights would exist under the law applicable to the relevant debt prior to the time that the SDRM (the legal basis for modifying 
the creditors' rights) became effective. Such retroactive application would not be problematic under US federal law or the law of the UK (Schwarcz 2004). On the other hand, were a state of the US to enact an SDRM, its constitutionality would be tested under the Contracts Clause of the US Constitution. ${ }^{33}$ Inconsistency of the SDRM with a fundamental public policy of the law governing the SDRM could impose another impediment.

The SDRM also might (and probably would) provide that an effective restructuring plan binds creditors worldwide, irrespective of a creditor's location (however determined), nationality, or relationship (or lack thereof) to the relevant insolvency state. As just noted in connection with pre-existing creditors, the extraterritorial application raises questions of constitutionality, power, and authority. In addition, the extraterritorial application also implicates the issue of whether such application is consistent with customary international law and any applicable treaties or other international agreements. In a similar context, Melissa Boudreau has examined whether the recent Greek "Mopping-Up Law" would constitute an invalid expropriation under international law if considered by a US court (Boudreau 2012). She describes the Mopping-Up Law as one that "would change local law to effectively incorporate a collective action clause in all untendered local-law bonds" and concludes that a claim of invalid expropriation would be unlikely to succeed (Ibid.). Boudreau also notes that such a law also must be evaluated under "the Greek Constitution, the European Convention on Human Rights and its Protocols, and unfair or inequitable treatment." 34

Finally, even if the SDRM and restructuring plan pass muster in all respects under the law governing he SDRM, that would not ensure the effectiveness before a court sitting in a state other than the relevant insolvency state. Such effectiveness is considered next in Part 5.2.

33 US Const. art. I, sec. 10 ("No State shall ... pass any ... Law impairing the Obligation of Contracts.") In his article in this volume, Steven Schwarcz expresses an unqualified opinion that if New York were to enact an SDRM, in the form of the model law that he proposes, a sovereign debtor's pre-enactment debt contracts governed by New York law could be modified under that law without violating with the Contracts Clause (Schwarcz [forthcoming]). While an analysis of the merits of his conclusion is beyond the scope of this paper, in my view the conclusion is questionable.

34 Boudreau cites Buchheit and Gulati 2010a and notes that the Buchheit-Gulati paper was subsequently published under a slightly different name Buchheit and Gulati 2010b. In a [recent] [forthcoming] book chapter Robert Howse considers the relationship between a sovereign debtor's obligation to pay and principles of public international law and the implications of public international law for sovereign debt restructuring processes (Howse [forthcoming]). 


\subsection{Enforcement State Recognition of Plan: Insolvency Judgment Recognition and Choice-of-Law (Private International Law) Analysis}

If an effective restructuring plan under the law governing the SDRM is binding on a creditor, then presumably neither a court of the relevant insolvency state nor a court of the sovereign debtor state would permit the creditor to enforce pre-plan debt according to pre-plan terms against assets subject to the court's jurisdiction. However, even under the circumstances mentioned in Part 5.1 - a plan binding on creditors, including pre-existing creditors, and extraterritorially applicable under the law of the relevant insolvency state - a creditor may seek to enforce pre-plan debt in another state ("enforcement state") against assets subject to the jurisdiction of the enforcement state. ${ }^{35}$ A court sitting in the enforcement state would be called upon to determine whether or not to recognize the plan (i.e. in this context, whether or not to permit enforcement in that state). For present purposes it is assumed that the enforcing creditor has overcome a debtor state's defense of sovereign immunity and pursued its claim to judgment and further that the relevant assets are not immune from execution, matters that are beyond the scope of this paper. ${ }^{36}$ Moreover, as a

35 A creditor also might challenge the effectiveness of a restructuring plan outside the context of enforcement. For example, if the sovereign debtor state has submitted itself to the jurisdiction of the courts of a state the law of which governs the creditor's debt contract, the creditor might challenge the plan in the courts of that state. This assumes an exception to or a waiver of sovereign immunity. Or, a creditor might challenge the effectiveness in the courts of the sovereign debtor state, again assuming sovereign immunity does not apply.

36 On immunity from execution, see Mooney 2012: pp. 224-30. In the prevailing absence of a widely adopted SDRM, Guzman and Stiglitz propose as part of an interim approach the restoration of strict sovereign immunity.

There is a single principle which countries could agree to which would restore a semblance of order to the global sovereign debt market: the restoration of sovereign immunity. ... There should be a global agreement that no country can surrender its sovereign immunity (even voluntarily). Such a restriction is particularly important given the political economy problems discussed earlier. It is too easy for a government today to surrender the sovereign immunity of some government in the future, in return for money that would enhance its popularity and the wealth of its supporters.

Guzman and Stiglitz (forthcoming). One wonders how the market would view the issuance of sovereign debt that is clearly legally unenforceable and as to which no remedy would exist in case of a default. Buchheit et al. have suggested a more modest approach (Buchheit et al. 2013). They called for modification of the 2012 Treaty Establishing the European Stability Mechanism 
conceptual matter, whether or not a court sitting in an enforcement state recognizes a restructuring plan - to the end that a creditor's pre-plan claim is or is not enforceable in a court sitting in that state - is not strictly a question of whether the creditor is "bound" by the plan. On a practical level, however, a creditor's inability to enforce pre-plan debt as a result of such a court's recognition of a plan effectively binds the creditor with respect to assets within the enforcement state's jurisdiction.

If the restructuring plan has become effective under the law of the relevant insolvency state pursuant to a judicial proceeding (i.e. administered or supervised by a tribunal of, or recognized by, the relevant insolvency state), then the issue presented to a court sitting in the enforcement state would be whether, under the law of that state, the court would recognize the effectiveness of the plan as an insolvency judgment (Mooney 2015, Part II.B.2.c.). On the other hand, if the restructuring plan has become effective under the law governing the SDRM pursuant to a purely out-of-court (albeit statutory, not contractual) arrangement, ${ }^{37}$ then the issue presented to a court in the enforcement state would be whether, under the choice-of-law rules of that state, the court would apply the law of the relevant insolvency state (under which the enforcing creditor would be bound by the plan and enforcement would not be permitted) $)^{38}$ (Ibid.).

\subsection{Implementation of an SDRM}

This part addresses a range of approaches for the implementation of an SDRM, to the end that it and a restructuring plan will be effective to bind creditors in courts outside the relevant insolvency state and the sovereign debtor state. As to all of the approaches, however, an SDRM and a restructuring plan made effective thereunder must be tested against the local law. Moreover, the issues of constitutional

(ESM) (Ibid.). Under the proposed modification, the assets and revenue streams of an ESM member state whose debt had been restructured in an ESM-approved restructuring would be immune from judicial process (Ibid.). This would create a safe haven for member state assets in the Eurozone were holdout creditors to seek enforcement (Ibid.).

37 The No-Tribunal SDRM approach, considered above in Part 4, would be such an out-of-court arrangement.

38 This was the approach taken in the restructuring of Greek debt under the "mopping up law" that effectively imposed CACs on debt contracts governed by the law of Greece (Boudreau 2012). Dissenting, "holdout" creditors generally would be bound by operation of a supermajority vote of creditors in an enforcement action outside of Greece inasmuch as most jurisdictions would respect the contractual choice-of-law provision. 
and other impediments, retroactivity as to pre-SDRM creditors, and extraterritorial application of an SDRM and a restructuring plan, discussed in Part 5.1, must be examined in this implementation context as well. ${ }^{39}$

\subsubsection{Multilateral Convention on Recognition and Choice of Law}

Under this approach adopting states would become parties (contracting states) to a multilateral convention (treaty). Each contracting state would be obligated to recognize restructuring plans under an SDRM as to which the law governing the SDRM is the law of another contracting state. The recognition obligation could be made applicable to plans made effective through an insolvency judgment or by virtue of a choice-of-law rule that applies the law governing the SDRM. The recognition obligation would apply only to plans made effective under an SDRM that met certain mandatory requirements as specified in the convention.

A contracting state would not be obligated under the convention to enact an SDRM that would be applicable to itself as a sovereign debtor for the restructuring of its own sovereign debt. Nor would it be obliged to enact an SDRM that would apply to the restructuring of any other state's sovereign debt.

\subsubsection{Reciprocal Model Law}

Instead of a multilateral convention on recognition and choice of law as described in Part 5.3.1, the same structure could be implemented through adoption by states of laws that incorporate the substance of a model law promulgated by an international organization. Typically such a model law would be developed with participation by governmental, intergovernmental, and NGO participants. As with the multilateral convention, adopting states would be obligated to recognize restructuring plans under the SDRM of another adopting state (i.e. a reciprocity feature), either by recognition of an insolvency judgment or application of the law governing the SDRM.

39 Note, however, that even if an SDRM and a restructuring plan would not be effective if enacted and made effective under a state's local law, that would not necessarily mean that the courts of that state would be prevented from recognizing another state's SDRM and a restructuring plan made effective thereunder or from applying the other state's law to the SDRM and restructuring plan. 


\subsubsection{Multilateral Convention or Reciprocal Model Law on Binding Creditors and Extraterritorial Application}

Instead of a multilateral convention or reciprocal model law based on the concepts of insolvency judgment recognition and choice of law, the same effects for restructuring plans under qualifying SDRMs could be achieved by a convention or model law that provided for the binding of all creditors and the extraterritorial application of a restructuring plan. However, because it would be binding only on adopting states, there would appear to be no particular advantages to this approach over the multilateral convention and reciprocal model law approaches explained in 5.3.1 and 5.3.2. Moreover, the novelty and breadth of this approach could harbor some impediments to its acceptance and application..$^{40}$

\subsubsection{Binding Creditors as Nationals of Adopting States}

As an adjunct to any of the approaches described in Parts 5.3.1, 5.3.2, or 5.3.3, a multilateral convention or reciprocal model law could further provide that nationals (Staker 2014: p. 319-20) of adopting states would be barred from enforcing prerestructuring debt during the pendency of a restructuring proceeding or negotiation and following the effectiveness of a restructuring plan..$^{41}$ Nationals also could be barred from transferring claims against the sovereign debtor state to nationals of non-adopting states, unless the transferees agreed to be bound by the same restrictions that are applicable to nationals of adopting states. This approach could be an important supplemental tool if adopted in states whose nationals hold significant amounts of external sovereign debt, such as the US and many European states.

40 Perhaps any such disadvantages could be overcome by adopting this approach through an amendment of the Articles of Agreement of the IMF that would bind all member states.

41 As a general matter a state can regulate its nationals anywhere, including imposing sanctions on citizens for noncompliance with the state's law. "States have an undisputed right to extend the application of their laws to their citizens (that is, those who have the nationality of the State), wherever they may be" (Staker 2014: p. 318). The provisions binding nationals also could be extended to apply to non-nationals that are controlled by a national of an adopting state by providing that actions of a person so controlled is an action of the controlling national. This approach has been employed under US law. See, e.g. 42 U.S.C. § 2000e-1(c) (prohibited practices of a corporation controlled by an employer "presumed to be engaged in by such employer."); Taylor v. Sturgell, 553 US 880, 895 (2008) (“[A] nonparty is bound by a judgment if she "assume[d] control' over the litigation in which that judgment was rendered."). Without such a provision and an effective prohibition on transfer the imposition of the terms of a convention or model law on nationals of adopting states might easily be subject to manipulation and evasion. 


\subsubsection{Law Governing Sovereign Debt: Harmonization and Expansion of Scope to Include an SDRM and Restructuring Plan}

As a further supplement to any of the approaches described in Parts 5.3.1, 5.3.2, or 5.3.3, a multilateral convention or reciprocal model law could provide that (i) the state's law that governs sovereign debt includes that state's adoption of a multilateral convention or reciprocal model law under any of those approaches, and (ii) holders of that debt are bound by any effective restructuring plan under the law governing the SDRM of that state or another adopting state. Under this approach, in the courts of any state adopting this rule, if the governing law were the law of a state that had adopted any of the approaches posited in Parts 5.3.1, 5.3.2, or 5.3.3, then the holder of the debt would be bound by any effective restructuring plan. Although this choice-of-law harmonization and expansion approach is in one sense quite modest and limited, given the dominance of certain laws governing sovereign debt (e.g. New York Law (the USA) and English law (the UK), the reach of any of these approaches could be extended significantly more broadly were one of these approaches to be adopted by the US and the UK.

Absent special choice-of-law rules such as those described in the preceding paragraph, the state's law that governs a debt contract normally would not dictate the application of that state's insolvency law to an insolvency proceeding of the relevant debtor (Mooney 2015, Part II.B.2.c.). Moreover, under the approaches considered here it is a state's recognition obligations or a state's choice-of-law rule that is the key issue. Indeed, it is entirely possible - and even highly likely - that many states that would become a party to a convention or model law as contemplated here would not enact an SDRM regime as a part of their local laws.

\section{Feasibility of Adoption}

The relative pros and cons of the contractual and statutory approaches to reforming the infrastructure for sovereign debt restructurings are well known and understood, even in the absence of any strong consensus (at least among legal academics) on the ideal approach (Mooney 2015, Part II.A.). And I shall leave to others speculation on and assessment of the political, economic, and financial realities that bear on the likelihood of the widespread acceptance and adoption of an SDRM. In this Part I offer a few observations on the feasibility of an SDRM that arise out of the analysis in the preceding Parts of the paper. 
To the extent that concerns about retroactive and extraterritorial application of an SDRM are a material impediment, ${ }^{42}$ an approach that focuses on recognition by the courts of one state of a restructuring plan that is effective under the law of another state, discussed above in Parts 5.3.1 and 5.3.2, may offer advantages over an approach that emphasizes its retroactive effects and extraterritorial application, considered in Part 5.3.3. The former approaches simply appear more conventional to the naked (legal) eye and avoid placing emphasis on traditionally controversial issues of retroactivity and extraterritorial prescriptive jurisdiction.

The relative merits of a multilateral international convention approach and a reciprocal model law approach also must be weighed. The former approach may be more time-consuming, expensive, and cumbersome, but the latter approach may carry less weight symbolically and politically and runs the risk of succumbing to failure through nonuniformity.

The Model CACs appear to be (or, at least, appear to be becoming) the market standard for new issues of sovereign debt. If this is the case, then an SDRM (such as the No-Tribunal SDRM described in Part 4 and the SDRM proposed in Framework) that embraces the voting structures contemplated by the Model CACs would appear to be normatively and practically compatible with that market standard. Given that, and if other objections (such as mistrust of any relevant tribunal or concerns over excessive and unfair manipulation by a debtor state) can be overcome, then it is plausible that such an SDRM would find favor (or at least open minds) among the sovereign debt underwriting and investor community. Nonetheless, investors holding preexisting, prerestructuring debt who have not agreed to be bound by a Model CAC regime with respect to that debt, much less to be bound by an SDRM, may raise objections. It is also likely that an investor in distressed sovereign debt who bought at prices much less than the face amount, and who hopes to recover the face amount (or at least substantially more that than the investor's purchase price) from the debtor state - the so-called "vulture funds" or "holdout creditors" - would not be happy with an SDRM that would bind a dissenting minority of creditors based on a supermajority vote. And it is not likely that states that object to an SDRM, such as the US, would change positions absent strong preferences for such a change being expressed by the investor community.

In recent years voluntary restructurings of sovereign debt securities have received very strong support from creditors, with more than $90 \%$ of debt holders accepting new securities in exchange offers in almost all cases (Moody's 2013). If any SDRM proposal is to be successful, then, it would seem that the dialogue must begin with the segments of the investor community that are open, in appropriate circumstances, to participation in voluntary sovereign debt restructurings.

42 Part 5.1 posits that these concerns may be significant. 


\section{Conclusion}

This paper explored the structure of an SDRM that would not be overseen or administered by any tribunal. This approach would overcome some significant objections that have been leveled against earlier proposals for an SDRM. The posited No-Tribunal SDRM would follow the voting procedures provided in the Model CACs. In that respect the approach would be vulnerable to some of the criticisms of a contractual approach under the Model CACs, such as issues of inter-creditor equity and the failure to take into account "informal" creditors (see Guzman and Stiglitz [forthcoming]). But I have not put on the table the NoTribunal SDRM and the other features of the SDRM proposed in Framework as optimal approaches. I have suggested their consideration with at least one eye (and perhaps both eyes) on those who have rejected the idea of an SDRM. If these approaches were to find some favor with the investor community, then perhaps the naysayers would be open to reconsideration as well.

This paper also focused on the various means by which a restructuring plan that emerges from a statutorily created SDRM could be implemented - i.e. made effective and binding against creditors of a debtor state. One approach would bind states to recognize foreign restructurings made effective under an SDRM that met specified mandatory standards. The recognition obligation could be imposed on a state by its adoption of a multilateral international convention or by its enactment of a model law along the same lines. Alternatively, a convention or model law could adopt a harmonized choice-of-law rule that would apply the law of the relevant insolvency state in the courts of the adopting state, also resulting in recognition of the restructuring plan. Another alternative would be a convention or model law that provided for retroactively binding creditors and extraterritorial application, but that approach would have no apparent advantages over the first two and might prove less acceptable. States adopting a convention or model law also could be bound to bar the state's nationals from enforcing pre-restructuring debt and binding its nationals by an effective restructuring plan. Another potential approach would provide that if an adopting state's law governed sovereign debt of a state, that law would include that state's obligations under a convention or model law and that holders of such debt would be bound by any effective restructuring plan.

The paper concludes with one further, final take-away. Even if a strong consensus were to emerge in the international financial community in favor of the adoption of an SDRM, one may not safely assume that every state would possess the power to adopt any particular structure of implementation. For example, a given state might be hindered by local constitutional or public policy constraints from recognizing an insolvency judgment approving a restructuring plan. But 
that state might nonetheless have the power to recognize the plan as a matter of its choice-of-law (private international law) rules. One size might not fit all. Given that and the menu of available choices for implementing an SDRM, it might be wise for any convention or model law on the subject to offer to potentially adopting states such a menu of optional approaches.

Acknowledgments: Charles A. Heimbold, Jr. Professor of Law, University of Pennsylvania Law School. A preliminary discussion draft of this paper was presented at the Conference on Sovereign Debt Restructuring, held on September 22, 2015, at Columbia University, sponsored by the Centre for International Governance Innovation and Columbia University Initiative for Policy Dialogue. The paper has benefited greatly from the comments and discussion at the Conference and from the constructive and thoughtful comments in the report of an anonymous peer reviewer.

\section{References}

Ad Hoc Committee on Sovereign Debt Restructuring Processes (Ad Hoc Committee) - General Assembly, 1st meeting, 69th Session (2015) Available from <http://webtv.un.org/watch/ ad-hoc-committee-on-sovereign-debt-restructuring-processes-general-assembly-1stmeeting-69th-session/4030566416001>.

Boudreau, Melissa A. (2012) "Restructuring Sovereign Debt Under Local Law: Are Retrofit Collective Action Clauses Expropriatory?” Harvard Business Law Review Online, 2:164-186. Available from <http://www.hblr.org/?p=2283.>.

Buchheit, Lee C. and G. Mitu Gulati (2010a) “How to Restructure Greek Debt,” Duke Law Working Papers, Paper No. 47. Available from <http://scholarship.law.duke.edu/working_ papers/47>.

Buchheit, Lee C. and G. Mitu Gulati (2010b) “Restructuring a Nation's Debt,” International Financial Law Review, 29:46-49.

Buchheit, Lee C., G. Mitu Gulati and I. Tirado (2013) "The Problem of Holdout Creditors in Eurozone Sovereign Debt Restructurings,” Butterworth's Journal of International Banking and Financial Law, April:191-194.

Buckley, Ross P. (2009) “The Bankruptcy of Nations: An Idea Whose Time Has Come," International Lawyer, 43: 1189-1216.

Economic and Financial Committee (EFC) of the European Union, Sub-committee on Sovereign Debt Markets (2012a) Euro Area Model Collective Action Clause: Common Terms of Reference. Available from: <http://europa.eu/efc/sub_committee/pdf/cac_-_text_model_cac.pdf>.

Economic and Financial Committee (EFC) of the European Union, Sub-committee on Sovereign Debt Markets (2012b). Collective Action Clause, Explanatory Note. Available from <http://europa.

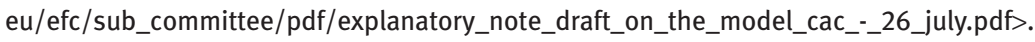

Economic and Financial Committee (EFC) of the European Union, Sub-committee on Sovereign Debt Markets (2014) Collective Action Clauses in Euro Area. Available from <http://europa. eu/efc/sub_committee/cac/index_en.htm>. 
European Union (EU) @ United Nations (2014) “EU Explanation of Vote - United Nations General Assembly: Draft Resolution: Sovereign Debt Restructuring," Available from <http://eu-un. europa.eu/articles/en/article_15833_en.htm>.

Gelpern, Anna (2013) “A Skeptic’s Case for Sovereign Bankruptcy,” Houston Law Review, 50:1095-1127.

Gianviti, François, Anne O. Krueger, Jean Pisani-Ferry, André Sapir and Jürgen Von Hagen (2010) “A European Mechanism for Sovereign Debt Crises Resolution: A Proposal," Bruegel Blueprint Series, 10:i-37.

Guzman, Martin and Joseph E. Stiglitz (forthcoming) "Fixing Sovereign Debt Restructuring." In: [insert], [page nos.], eds.)Too Little, Too Late: The Quest to Resolve Sovereign Debt Crises. New York: Columbia University Press.

Hagan, Sean (2005) “Designing a Legal Framework to Restructure Sovereign Debt," Georgetown Journal of International Law, 36:299-402.

Howse, Robert (forthcoming) “Towards a Framework for Sovereign Debt Restructuring: What Can Public International Law Contribute?” In: ([insert], [page nos.], eds.) Too Little, Too Late: The Quest to Resolve Sovereign Debt Crises. New York: Columbia University Press.

Hoffman, Christian (2014) "Sovereign-Debt Restructuring in Europe Under the New Model Collective Action Clauses," Texas International Law Journal, 49:383-441.

International Capital Market Association (ICMA) (2014) "Standard Aggregated Collective Action Clauses (CACs) for the Terms and Conditions of Sovereign Notes" (Model CACs). Available from < http://www.icmagroup.org/resources/icma-documentation/>.

International Monetary Fund (IMF) (2013) "Sovereign Debt Restructuring - Recent Developments and Implications for the Fund's Legal and Policy Framework.” Available from < https://www.imf.org/external/np/pp/eng/2013/042613.pdf>.

Krueger, Anne 0. (2002) A New Approach to Sovereign Debt Restructuring. Available from <http://www.imf.org/external/pubs/ft/exrp/sdrm/eng/sdrm.pdf>.

Lee, Ashley (2014a) “New ICMA Clauses Debut in Kazakhstan Sovereign," International Financial. Law Review, Available from <http://www.iflr.com/Article/3390692/New-ICMAclauses-debut-in-Kazakhstan-sovereign.html.>.

Lee, Ashley (2014b) “Viet Nam's ICMA CAC First Explained,” International Financial Law Review, Available from <http://www.iflr.com/Article/3404031/Search/Results/Vietnams-ICMACAC-first-explained.html?Pageld=201737\&Keywords=Viet+Nam+ICMA+CAC\&OrderType=1 \&PartialFields=(CATEGORYIDS\%3a14718).>.

Moody's Investor Service, Sovereign Defaults Series (Moody’s) (2013) "The Role of Holdout Creditors and CACs in Sovereign Debt Restructurings."

Mooney, Jr., Charles W. (2012) "United States Sovereign Debt: A Thought Experiment on Default and Restructuring." In: Is U. S. Government Debt Different? Philadelphia: Wharton Financial Institutions Center Press, pp. 169-235. Available from <http://papers.ssrn.com/ sol3/papers.cfm?abstract_id $=2520062 \mathrm{~A}>$.

Mooney, Jr., Charles W. "A Framework for a Formal Sovereign Debt Restructuring Mechanism: The KISS (Keep it Simple, Stupid) Principle and Other Guiding Principles," Michigan Journal of International Law, 37 (forthcoming).

Muchhala, Bhumika (2014) "Historic UN General Assembly Vote on a Multilateral Sovereign Debt Mechanism," Third World Network, Available from <http://www.twn.my/title2/ unsd/2014/unsd140903.htm5>.

Orzan, Andrea (2004) "Sovereign Debt Restructuring Mechanism: Who Opposes It and Why?” Centro de Investigación Latinoamérica Europa, Nota Técnica NT/02/04. Available from <http://www.cilae.org/publicaciones/SDRM.pdf.>. 
Paulus, Christoph G. (2013) “A Resolvency Proceeding for Defaulting Sovereigns.” In: (Patrick S. Kendajian, Klaus-Albert Bauer and Andreas Cahn, eds.) Institute for Law and Finance Series: Collective Action Clauses and the Restructuring of Sovereign Debts. Berlin: De Gruyter, 12. pp. 181-205.

Paulus, Christoph G. and Ignacio Tirado (2013) "Sweet and Lowdown: A Resolvency Process and the Eurozone's Crisis Management Framework.” In: (Capriglione, F., R. M. Lastra, R. McCormick, C. Paulus, L. Reichlin and M. Sakuramoto, eds.) Law and Economics Yearly Review. London: Fondazione Gerardo Capriglione Onlus, 2. pp. 504-559.

Paulus, Christoph G. ed. (2014) A Debt Restructuring Mechanism for Sovereigns: Do We Need a Legal Procedure? Munich: Beck, Hart, \& Nomos.

Riesenfeld, Stephan (1987) Creditors' Remedies and Debtors' Protection. St. Paul, Minnesota: West Publishing.

Schwarcz, Steven L. (2004) “'Idiot’s Guide’ to Sovereign Debt Restructuring,” Emory Law Journal, 53:1189-1218.

Schwarcz, Steven L. (forthcoming) “Sovereign Debt Restructuring: A Model Law Approach,” Journal of Globalization and Development.

Staker, Christopher (2014) “Jurisdiction.” In: (Malcolm D. Evans, ed.) International Law. Oxford: Oxford University Press, pp. 309-335.

Thomas, Zoe (2015) “Sovereign Bond Clauses Grow in Popularity," International Financial Law Review, Available from http://www.iflr.com/Article/3419256/Search/Results/ Sovereign-bond-clauses-grow-in-popularity.html?Pageld=201737\& Keywords=Mexico+lC $M A+C A C \&$ OrderType $=1 \&$ PartialFields $=($ CATEGORYIDS\%3a14718).$>$.

United Nations (UN) (2015) Ad hoc Committee on Sovereign Debt Restructuring Processes, Third Working Session, Committee Report, Second Part: Chairperson Summary. Available From <http://www.unctad.info/upload/Gong/Final\%20Chairs\%20Summary\% 20July\%2024,\%205\%2030pm.pdf.>.

United Nations Conference on Trade and Development (UNCTAD) (2015a) Ad-Hoc Committee on Sovereign Debt Restructuring Processes and Informal Substantive Sessions. Available from http://www.unctad.info/en/Debt-Portal/Events/Our-events/ GAG77-events-on-Legal-Framework-for-Debt-Restructuring-Processes/Ad-hoc-committeeand-informal-substantive-sessions/.

United Nations Conference on Trade and Development (UNCTAD) (2015b) Second Ad Hoc Committee Session. Available from <http://www.unctad.info/en/Debt-Portal/Events/ Our-events/GAG77-events-on-Legal-Framework-for-Debt-Restructuring-Processes/ Ad-hoc-committee-and-informal-substantive-sessions/Second-ad-hoc-committeesession-28-30-April-2015--/>.

United Nations Conference on Trade and Development (UNCTAD) (2015c) Sovereign Debt Workouts: Going Forward, Roadmap and Guide Available from <http:// unctad.org/en/pages/newsdetails.aspx?OriginalVersionID=987\&Sitemap_ x0020_Taxonomy=UNCTAD\%20Home;\#4;\%23Globalization\%20and\%20 Development;\%231705;\%23Debt\%20and\%20Development\%20Finance>. 